\title{
PENGARUH PEMBERIAN INFORMASI DENGAN APLIKASI WHATSAPP TERHADAP PENGETAHUAN REMAJA TENTANG HIV DAN AIDS
}

\section{THE EFFECT OF INFORMATION INTERVENTION USING WHATSAPP ON YOUTH KNOWLEDGE REGARDING HIV AND AIDS}

\author{
Herlin Fitriana Kurniawati ${ }^{1}$, Kharisah Diniyah ${ }^{2 *}$ \\ ${ }^{1}$ Universitas Aisyiyah Yogyakarta, Jalan Siliwangi No. 63 Mlangi Nogotirto Gamping Sleman, \\ email: herlinana@gmail.com, Indonesia \\ ${ }^{*}$ Universitas Aisyiyah Yogyakarta, Jalan Siliwangi No. 63 Mlangi Nogotirto Gamping Sleman, \\ email: kharisa188@gmail.com, Indonesia
}

\begin{abstract}
Background: Yogyakarta has crucial health problem which is the rise of free sex incidence on youth which can lead to HIV and AIDS. One strategy to overcome this problem is by providing correct and easily accessible information of HIV/AIDS. Submission of the information is done through WhatsApp group application by considering the number of users and ease of information access through the application.

Objective: This study aimed to investigate the effect of information intervention using whatsapp on youth knowledge regarding HIV and AIDS in the Temon Kulon Progo district of Yogyakarta.

Methods: A pre-experimental study with one group pretest and post test design was applied to 50 respondents using purposive sampling. Data were gathered by employing questionnaires and then analized by using Wilcoxon Matched Pairs test.

Results: The results showed that there was an effect of giving information with whatsapp application to adolescent knowledge about HIV and AIDS in the Temon Kulon Progo district of Yogyakarta ( $z=-6,193$; $\mathrm{p}<0,05)$.

Conclusion: Information intervention by using WhatsApp can escalate the knowledge of youth regarding HIV and AIDS.
\end{abstract}

Keywords: HIV and AIDS, Whatsapp, Teenagers

\section{PENDAHULUAN}

Perkembangan permasalahan Human Immunodeficiency Virus (HIV) dan Acquired Immune Deficiency Syndrome (AIDS) semakin lama semakin mengkhawatirkan baik dari sisi kuantitatif maupun kualitatif. Indonesia menjadi negara urutan kelima di Asia paling berisiko HIV dan AIDS. HIV merupakan salah satu penyakit menular yang dikelompokkan sebagai faktor yang dapat memengaruhi kematian. Jumlah kasus HIV dan AIDS yang tercatat sebenarnya jauh lebih kecil daripada prevalensi sesungguhnya sebagai fenomena Gunung Es. ${ }^{1}$

Berdasarkan data Direktorat Jenderal
Pencegahan dan Pengendalian Penyakit Kemenkes RI (2016) Laporan Perkembangan Tri wulan 1 (Januari Maret) tahun 2016 didapatkan hasil bahwa jumlah kasus HIV yang dilaporkan sebanyak 7.146 orang, sedangkan untuk kasus AIDS sebanyak 305 orang. Persentase infeksi HIV tertinggi dilaporkan pada kelompok umur 25-49 tahun $(69,7 \%)$, kelompok umur 20-24 tahun $(16,6 \%)$, dan kelompok umur $\geq 50$ tahun (7,2\%). Sedangkan untuk persentase AIDS tertinggi pada kelompok umur 30-39 tahun $(37,7 \%)$, kelompok umur 20-29 tahun $(29,9 \%)$, dan kelompok umur 40-49 tahun (19\%). Persentase faktor risiko HIV tertinggi 
adalah hubungan seks berisiko pada heteroseksual (47\%), Lelaki Seks Lelaki (LSL) (25\%), lain-lain (25\%), pengguna jarum suntik tidak steril pada pengguna narkotika suntik (3\%). Persentase faktor risiko AIDS tertinggi adalah hubungan seks berisiko pada heteroseksual (73,8\%), Lelaki Seks Lelaki (LSL) (10,5\%), pengguna jarum suntik tidak steril pada pengguna narkotika suntik $(5,2 \%)$, dan perinatal (2,6\%). Hal tersebut menunjukkan faktor risiko HIV dan AIDS didominasi dengan hubungan seks berisiko pada heteroseksual. $^{2}$

Perhimpunan Dokter Spesialis Kulit dan Kelamin Provinsi Daerah Istimewa Yogyakarta (PERDOSKI DIY) mengungkapkan penderita HIV/AIDS yang sebelumnya merupakan orang dewasa, kini mulai bergeser menjadi berusia 20-24 tahun. Berdasarkan data PKBI Kabupaten Kulon Progo ditemukan bahwa kasus HIV-AIDS di Kabupaten Kulon Progo mengalami tren peningkatan, dari 158 pada 2015 sampai dengan November 2016 jumlahnya bertambah menjadi 177 kasus. ${ }^{3}$

Secara nasional jumlah penderita HIV dan AIDS di Kulon Progo masih sedikit dibandingkan daerah-daerah lain di Indonesia atau kota besar lainnya, akan tetapi yang memprihatinkan adalah dengan meningatnya kasus penderita HIV dan AIDS di kalangan remaja DIY. Guna mengantisipasi penyebaran penyakit ini di kalangan remaja yang lebih luas lagi, PERDOSKI DIY melakukan sejumlah penyuluhan bagi kalangan pelajar, khususnya yang saat ini tengah duduk di bangku Sekolah Menengah Atas. ${ }^{4}$

Pemberian informasi yang diikuti dengan penjelasan secara mendalam mengenai penyakit Infeksi Menular Seksual (IMS) serta HIV dan AIDS dan penularannya ini, bertujuan memberikan pengetahuan dan pemahaman akan bahayanya seks bebas serta dua penyakit tersebut. Hal tersebut dilakukan dengan harapan agar ke depan kalangan remaja lebih memahami bagaimana penularan HIV/AIDS, agar perkembangan jumlah penderita HIV/AIDS bisa terus ditekan.

Pemberian informasi merupakan bentuk komunikasi yang bertujuan untuk meningkatkan pengetahuan. Komunikasi memungkinkan terjadinya kerjasama sosial, membuat kesepakatan - kesepakatan penting dan lain sebagainya. Penggunaan telepon pintar, dapat dimanfaatkan untuk mengakses berbagai layanan aplikasi yang tersedia berupa chatting atau mengobrol dengan teman, sahabat, guru, maupun orang tua.

Aplikasi instan telah berhasil disukai oleh penduduk dunia, termasuk juga remaja di Indonesia. Pengguan internet di Indonesia didominasi oleh generasi muda, sebanyak $82 \%$ pada rentang usia 20-24 tahun. ${ }^{5}$

Adapun salah satu layanan yang dapat bebas digunakan untuk berkomunikasi dengan menggunakan perangkat telepon genggam adalah aplikasi WhatsApp". WhatsApp dapat digunakan untuk 
berkomunikasi kapan dan dimanapun dengan orang yang memiliki aplikasi serupa selama kita tersambung dengan koneksi data internet.Data yang disajikan oleh Playstore sebagai penyaji aplikasi berbasis Android menunjukkan bahwasanya WhatsApp menduduki peringkat paling tinggi yang diunduh oleh masyarakat dibandingkan dengan aplikasi komunikasi mobile lainnya.

Berdasarkan uraian latar belakang di atas, maka rumusan masalah pada penelitian ini adalah apakah ada pengaruh pemberian informasi dengan aplikasi whatsapp terhadap pengetahuan remaja tentang HIV dan AIDS di Kecamatan Temon Kulon Progo Yogyakarta? Tujuan dari penelitian ini adalah untuk mengetahui pengaruh pemberian informasi dengan aplikasi whatsapp terhadap pengetahuan remaja tentang HIV dan AIDS di Kecamatan Temon Kulon Progo Yogyakarta.

\section{BAHAN DAN CARA PENELITIAN}

Metode penelitian yang digunakan yaitu Pre-experimental design dengan rancangan penelitian one group pretest posttest. ${ }^{6}$

Populasi dalam penelitian ini adalah remaja yang tercatat sebagai pelajar kelas XI di SMA N 1 Temon Kulon Progo Yogyakarta dengan kriteria inklusi memiliki telepon genggam android yang dapat digunakan untuk operasi aplikasi whatsapp, dan bersedia menjadi responden. Teknik pengambilan sampel dengan purposive sampling sebanyak 50 responden. Instrumen yang digunakan menggunakan kuesioner, yang berisi pengetahuan tentang profil HIV dan AIDS, cara penularan, masa inkubasi, cara pencegahan, cara mendiagnosa, pemeriksaan laboratorium untuk menegakkan diagnose, serta dampak HIV/ AIDS.

Kuesioner ini diberikan dua kali, pertama sebagai pre test sebelum diberi perlakuan berupa pemberian informasi melalui whatsapp, dan yang kedua diberikan pada saat post test dua bulan kemudian. Setelah diberikan pre test, seluruh responen dimasukkan dalam satu group whatsapp, yang kemudian diberikan informasi tentang HIV dan AIDS.

Informasi mengenai profil HIV dan AIDS, cara penularan, masa inkubasi, cara pencegahan, cara mendiagnosa, pemeriksaan laboratorium untuk menegakkan diagnose, serta dampak HIV/ AIDS, yang dikirim secara bertahap dibagi menjadi 3, serta diberikan kesempatan pada seluruh anggota group untuk mendiskusikan setiap materi yang dikirim Analisis data menggunakan Wilcoxon Signed-Rank Test.

\section{HASIL DAN PEMBAHASAN}

Penelitian ini menggunakan responden sebanyak 50 orang, yaitu siswa kelas XI SMA 1 Temon. Karakteristik responden dapat dilihat pada tabel 1. 
Tabel 1. Distribusi karakteristik responden $(\mathrm{N}=50)$

\begin{tabular}{lcc}
\hline $\begin{array}{c}\text { Karakteristik } \\
\text { Responden }\end{array}$ & Frekuensi & $\begin{array}{c}\text { Persentase } \\
(\%)\end{array}$ \\
\hline $\begin{array}{l}\text { Jenis Kelamin } \\
\text { Laki-laki }\end{array}$ & 16 & 32 \\
$\quad$ Perempuan & 34 & 68 \\
$\quad$ Total & 50 & $\mathbf{1 0 0}$ \\
Umur & 1 & 2 \\
15 tahun & 17 & 34 \\
16 tahun & 32 & 64 \\
17 tahun & $\mathbf{5 0}$ & $\mathbf{1 0 0}$ \\
$\quad$ Total & & \\
Media Whatsapp & & \\
Lama & & \\
Penggunaan & & 0 \\
$<2$ tahun & 0 & 76 \\
$2-5$ tahun & 38 & 24 \\
5 tahun & 12 & $\mathbf{1 0 0}$ \\
Total & $\mathbf{5 0}$ & \\
Durasi & & 0 \\
Penggunaan & & 100 \\
$<1$ jam/hari & 0 & $\mathbf{1 0 0}$ \\
1-2 jam/hari & 0 & \\
2 jam/hari & 50 & \\
Total & $\mathbf{5 0}$ & \\
\hline
\end{tabular}

Sumber: Data Primer 2018.

Berdasarkan tabel 1. menunjukkan bahwa mayoritas responden adalah berjenis kelamin perempuan (68\%); berumur 17 tahun (64\%); telah menggunakan whatsapp selama 2-5 tahun (76\%); dan seluruh responden menggunakan aplikasi ini dengan durasi penggunaan terberat yaitu lebih dari 2 jam/hari. Adapun pengetahuan remaja tentang HIV dan AIDS pre dan post pemberian informasi dengan media whatsapp, sebagai berikut:

Tabel 2. Pengetahuan pengetahuan remaja tentang HIV dan AIDS ( $\mathrm{N}=50)$

\begin{tabular}{llcccc}
\hline No & $\begin{array}{l}\text { Penge- } \\
\text { tahuan }\end{array}$ & \multicolumn{2}{c}{ Pre } & \multicolumn{2}{c}{ Post } \\
\hline & & $\begin{array}{c}\text { Fre- } \\
\text { kuensi }\end{array}$ & $(\%)$ & $\begin{array}{c}\text { Fre- } \\
\text { kuensi }\end{array}$ & $(\%)$ \\
\hline 1. & Kurang & 10 & 20 & 0 & 0 \\
2. & Cukup & 24 & 48 & 3 & 6 \\
3. & Baik & 16 & 32 & 47 & 94 \\
& Total & 50 & 100 & 50 & 100
\end{tabular}

Sumber: Data Primer 2018.
Berdasarkan hasil penelitian secara statistik terjadi perubahan pengetahuan remaja tentang HIV dan AIDS dimana mayoritas remaja berada pada kategori cukup (48\%) sebelum diberikan intervensi, sedangkan setelah diberikan intervensi mayoritas berada pada kategori baik (94\%).

Tabel 3. Hasil analisa uji Wilcoxon data pemberian Informasi dengan media Whatsapp terhadap pengetahuan

\begin{tabular}{ccc}
\hline & Nilai & Nilai $p$ \\
\hline $\begin{array}{c}\text { Pretest dan } \\
\text { posttest }\end{array}$ & $-6,193$ & 0,000 \\
\hline
\end{tabular}

Uji statistik menggunakan Wilcoxon Signed-Rank Test menunjukkan nilai $\mathrm{z}=-$ $6,193(p<0,05)$ yang berarti secara statistik terdapat pengaruh yang signifikan dari pemberian informasi tentang HIV dan AIDS melalui media whatsapp pada responden terhadap pengetahuan remaja tentang HIV dan AIDS

Pengetahuan tentang HIV/AIDS dapat diperoleh melalui media informasi yang menjadi perantara dalam menyampaikan informasi, merangsang pemikiran dan kemampuan serta menambah pengetahuan. Sumber informasi dapat di peroleh melalui media cetak (surat kabar, majalah, buku), media elektronik (televisi, radio, internet). Akibatnya, seseorang yang lebih sering terpapar media massa akan memperoleh informasi lebih banyak dibanding orang yang tidak terpapar media massa. Ini berarti, paparan media massa mempengaruhi tingkat pengetahuan seseorang.

Hasil penelitian ini sejalan dengan penelitian sebelumnya yang menyatakan 
bahwa paparan seseorang terhadap media informasi meningkatkan pengetahuan tentang HIV. Pengetahuan HIV berhubungan dengan sikap dalam menerima seseorang yang terserang virus HIV. Berdasarkan hasil penelitian menunjukkan bahwa peluang pemberian informasi atau peningkatan pengetahuan remaja tentang HIV dan AIDS sangat bisa diberikan menggunakan media sosial atau internet. ${ }^{7}$

Perkembangan teknologi informasi yang pesat saat ini khususnya perkembangan teknologi internet semakin mempermudah dalam pemilihan alternatif metode promosi kesehatan.Teknologi internet di lingkungan SMA 1 Temon dapat diakses kapan saja dan dimana saja, dapat digunakan oleh seluruh civitas akademika yang ada. Sehinga siswa lebih mudah mengakses ataupun menggunakan media sosial yang ada di smartphone. Aplikasi media sosial terbukti memudahkan dalam proses berbagi pengetahuan. $^{8}$

Media massa atau informasi yang diperoleh baik dari formal maupun non formal dapat memberikan pengaruh jangka pendek sehingga menghasilkan perubahan atau peningkatan pengetahuan. Seiring berkembangnya media massa dapat mempengaruhi pengetahuan masyarakat tentang inovasi baru. Media massa sebagai sarana informasi mempunyai pengaruh besar terhadap pembentukan opini dan kepercayaan seseorang. ${ }^{9}$
Berdasarkan durasi penggunaan WhatsApp diperoleh hasil bahwa semua responden menyatakan bahwa menggunakan dengan durasi lebih dari 2 jam per hari (pengguna berat). Penggunaan media sosial sudah tidak hanya sebagai bentuk untuk mendapatkan informasi, akan tetapi sudah menjadi kebiasaan atau ritual. ${ }^{8}$

Media sosial merupakan salah satu pengaruh besar dalam pembentukan opini dan kepercayaan orang, dengan adanya media sosial yang membawakan informasi akan memberikan dasar afektif dalam menilai suatu hal sehingga terbentuklah arah sikap tertentu. ${ }^{10}$ Responden yang mendapatkan informasi dari media sosial dengan kategori pengguna berat dapat dikarenakan akses media sosial pada remaja sekarang ini semakin mudah. Media sosial merupakan salah satu alat atau perantara yang modern digunakan oleh seseorang untuk berinteraksi dan berkomunikasi tanpa adanya hambatan dan penghalang seperti batasan umur, jenis kelamin, jenis pekerjaan ataupun batasan negara, sehingga menjadi daya tarik bagi remaja dalam menggunakan media sosial karena tidak terbatas dengan apapun.

\section{KESIMPULAN}

Sebagian besar pengetahuan pretest responden dalam kategori cukup baik sebanyak 24 responden (48\%), dan paling sedikit dalam kategori kurang sebanyak 10 responden (20\%). Sedangkan pengetahuan postest sebagian besar dalam kategori baik 
sebanyak 47 responden (94\%) dan tidak terdapat responden dengan nilai kurang.

Terdapat pengaruh Pemberian
Informasi Dengan Media WhatsApp

Terhadap Pengetahuan Remaja Tentang HIV

Dan AIDS dengan $p$ value sebesar 0,000.

Sehingga media sosial berupa whatsapp dapat dijadikan alternative dalam memilih sarana promosi kesehatan reproduksi kepada remaja.

\section{TERIMA KASIH}

1. Kementerian Riset, Tehnologi, dan Pendidikan Tinggi.

2. Warsiti,S.Kp.,M.Kep.,Sp.Mat., selaku Rektor Universitas Aisyiyah Yogyakarta.

3. M. Ali Imron,S.Sos.,M.Fis, selaku Dekan Fakultas IImu Kesehatan Universitas Aisyiyah Yogyakarta.

4. Drs. Agus Nur Khafid, Kepala Sekolah SMA 1 Temon Kulon Progo.

\section{KEPUSTAKAAN}

1. Kemenkes RI. Pedoman Nasional ManajemenProgram HIV dan AIDS [Internet]. Jakarta: DirektoratJenderal Pengendalian Penyakit dan Penyehatan Lingkungan; 2015. Available from: http://siha.depkes.go.id/portal/files upl oad/Pedoman Manajemen PPIApdf.p df

2. Kemenkes RI. Laporan Kinerja Direktorat Jendral Pencegahan dan Pengendalian Penyakit [Internet]. Jakarta; 2016. Available from: http://depkes.go.id/resources/downloa d/LAKIP2017/5 LKj Es 1 2016/2. Lkj Ditjen P2P Tahun 2016 .pdf

3. Mardiya, Sutari E. Kulon Progo Bangkit Tanggulangi AIDS [Internet]. Kulon Progo; 2010. Available from: http://kulonprogokab.go.id/v3/portal/we b/view berita/1317/details 2

4. Dwianjani M. Penderita HIV/AIDS Kini Didominasi Remaja dan Ibu-ibu. Kabar Handayani [Internet]. Gunung Kidul Yogyakarta; 2016; Available from: http://kabarhandayani.com/penderitahivaids-kini-didominasi-remaja-danibu-ibu/

5. Sugiharto BA. Pengguna Internet di Indonesia Didominasi Anak Muda. Jakarta; 2016; Available from: https://www.cnnindonesia.com/teknolo gi/20161024161722-185-

167570/pengguna-internet-diindonesia-didominasi-anak-muda

6. Notoatmodjo S. Penelitian Kesehatan. Jakarta: Rineka Cipta; 2010.

7. Babaloa S, Fatusi A, Anyanti J. Media saturation, communication exposure and HIV stigma in Nigeria. Elsevier Soc Sience Med [Internet]. 68(8):1513 20. Available from: https://www.sciencedirect.com/science /article/abs/pii/S0277953609000434?vi a\%3Dihub

8. Fardila Soliha S. Tingkat Ketergantungan Pengunaan Media Sosial Dan Kecemasan Sosial. J Interak [Internet]. 2015;4. Available from:

http://download.portalgaruda.org/article .php

9. Notoatmodjo S. Promosi Kesehatan Dan IImu Perilaku. Jakarta: Rineka Cipta; 2012.

10. Azwar. Sikap Manusia; Teori dan Pengukurannya. Yogyakarta: Pustaka Pelajar; 2015. 